\title{
Munnheilsa barna sem búa við erfiðar félagslegar aðstæður - áskorun
}

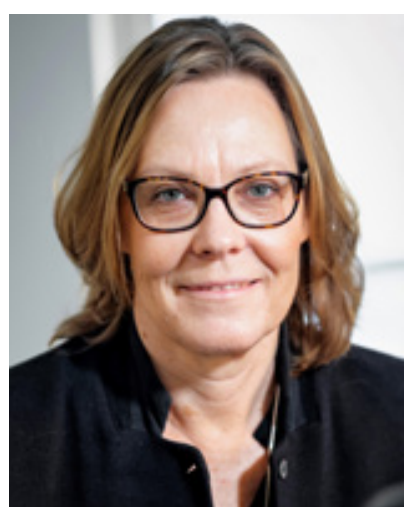

GUNILLA KLINGBERG, CAND. ODONT, DR.ODONT, REKTOR, PRÓFESSOR Í BARNATANNLAEKNINGUM, TANNLAEKNADEILD HÁSKÓLANS Í MALMÖ, SVÍPJÓĐ KARIN RIDELL,CAND.ODONT DR.ODONT, LEKTOR Í BARNATANNLAEKNINGUM, TANNLAEKNADEILD HÁSKÓLANS Í MALMÖ, SVÍPJÓĐ

MARIT SLÅTTELID SKEIE, CAND.ODONT, DR. ODONT, PRÓFESSOR EMERITUS, DEILD KLIINÍSKRA TANNLAEKNINGA BARNATANNLAEKNINGAR. TANNLAEKNADEILD HÁSKÓLANS Í BERGEN, NOREGI, EINNIG HJÁ FAGMIĐSTÖĐ TANNHEILSU MIĐ-NOREGS, PRÁNDHEIMI, NOREGI

TENGILIĐUR: GUNILLA KLINGBERG, MALMÖ UNIVERSITET, ODONTOLOGISKA FAKULTETEN, SE 20506 MALMÖ, SVERIGE, gunilla.klingberg@mau.se SAMPYKKT AF RITSTJÓRN PEMAVERKEFNIS TIL BIRTINGAR 18. MAÍ 2020

TANNLAEKNABLAĐIĐ 2020; 38: 88-95

doi: $10.33112 / \operatorname{tann} .38 .1 .10$

\section{ÁGRIP}

Allir sem vinna með börn ættu að pekkja til Barnasáttmála Sameinuðu pjóðanna, en samkvæmt honum ættu öll börn að hafa jafnan rétt til bestu mögulegu heilsu. Prátt fyrir góða munnheilsu á Norðurlöndunum, sýna rannsóknir að börn, sem búa við erfiðar félagslegar aðstæður, séu líklegri til að búa við slæma munnheilsu. Forvarnaraðgerðir ná ekki til peirra, pau nýta sér sjaldnar tannlæknapjónustu og njóta skertrar tannverndar, samanborið við önnur börn. Af peim sökum er, auk almennra forvarnaraðgerða, pörf fyrir sérsniðnar aðgerðir fyrir áhættuhópa til að ná til peirra barna sem búa við erfiðar félagslegar aðstæður. Einnig er mikilvægt að fræðslu- og forvarnarstarf hefjist á unga aldri. pekkingu um áhrif mismunandi aðferða við forvarnir og meðferð skortir og hagfræðilegir útreikningar peim tengdir eru fáir. pað er mikil áskorun að skrá og meta á kerfisbundinn hátt tanntengdar fræðslu-og forvarnaraðgerðir ætlaðar börnum sem búa við erfiðar félagslegar aðstæður, svo nýta megi til rannsókna. pörf er á pverfaglegum rannsóknum með aðkomu tannlæknastofa. Framtíðarsýnin er að jafnrétti til heilsu sé tryggt og að heilsueflandi fræðsla og forvarnir dragi úr ójöfnuði í munnheilsu á milli ólíkra pjóðfélagshópa.

Lykilorð: Tannlæknapjónusta, börn, félags-og fjárhagslegir pættir, munnheilsa, forvarnir. 


\section{Inngangur}

Tannheilsa barna og ungmenna á Norðurlöndunum er almennt góð í samanburði við mörg önnur lönd (1). Pað skýrist að mestu af skilvirkri gjaldfrjálsri tannlæknabjónustu fyrir börn, ásamt öflugu velferðarkerfi. prátt fyrir pað fyrirfinnast börn sem búa við verri tannheilsu og tannlæknapjónusta nær ekki til sökum ýmissra félagslegra erfiðleika. Á sama tíma ber tannlæknapjónustu, út frá heilbrigðissjónarmiði, skylda til að setja munnheilsu barna í forgang. Með fyrirbyggjandi aðgerðum ætti að vera hægt að koma í veg fyrir tannátu hjá stórum hluta barna. Sé unnt að koma í veg fyrir tannátu hjá börnum allt fram á fullorðinsár og um leið kenna peim að bera ábyrgð á munnheilsu sinni, má sennilega draga bæði úr tannátu hjá fullorðnum og pörf fyrir tannviðgerðir. Slík nálgun felur líklega í sér ávinning bæði hvað varðar heilsu og pjóđarbú. Fjárfesting í munnheilsu barna hefur pví margar jákvæðar hliðar.

Tilgangur pessarar greinar er að lýsa mismunandi félagslegum aðstæðum sem hafa áhrif á munnheilsu barna. Ennfremur er gerð grein fyrir Barnasáttmála Sameinuðu pjóðanna og peirri ábyrgð sem hann setur á samfélagið til að standa vörð um rétt barna til heilsu. Með petta að leiðarljósi er fjallað um mismunandi aðferðir og áskoranir sem starfsfólk tannlæknapjónustunnar stendur frammi fyrir.

\section{Barnasáttmálinn}

Pað er óhugsandi að fjalla um munnheilsu barns eða áhrif félagslegra pátta á heilsu án pess að hefja máls á sáttmála Sameinuðu pjóðanna um réttindi barns (2). Barnasáttmálinn varð nýlega 30 ára að aldri og hefur verið sampykktur af öllum aðildarríkjum Sameinuðu pjóðanna nema Bandaríkjunum. Sáttmálinn var áđur innleiddur í lög í Finnlandi, Íslandi og í Noregi og um áramótin 2020 varð sáttmálinn einnig að lögum í Svípjóð (3).

Í sáttmálanum eru börn skilgreind sem einstaklingar yngri en 18 ára og eru settar fram fjórar meginreglur (greinar 2, 3, 6 og 12). Reglurnar fjalla um að börnum sé ekki mismunað, að hagsmunir barna séu i fyrirrúmi i málum sem pau varða, að börn hafi rétt til proska og að börn hafi rétt til að láta skoðanir sínar í ljós og tjá sig um eigin málefni. Í enn einni grein (24. grein) er staðfest að börn eigi rétt á bestu mögulegu heilsu, aðgengi að heilbrigðis-og sjúkrahúspjónustu, ásamt endurhæfingu. Tvær aðrar greinar eru mikilvægar pegar rætt er um félagslegar aðstæður barna og heilsu í pví samhengi. Í 26. og 27. gr. segir að börn eigi rétt á félagslegu öryggi og stuðningi ríkisins búi forráðamenn við bágar fjárhagsaðstæður. Ennfremur að börn eigi rétt á sanngjörnum lífskjörum er varðar grunnparfir á borð við húsnæði, fæði og klæði.

Barnasáttmálinn tryggir börnum tiltekin réttindi og samfélagið gegnir skyldum við að tryggja að öll börn fái sömu tækifæri til góðrar munnheilsu óháð bakgrunni, félags-og fjárhagsaðstæðum eða fötlun. Best væri ef börn yrðu auk pess hluti af ferlinu pegar ákvarðanir eru teknar um hvernig tannlæknapjónustu skuli háttað, hvers konar tannlæknapjónusta er mikilvæg o.s.frv. Samkvæmt sáttmálanum er mikilvægt að stefnumótandi aðilar, embættismenn, heilbrigðisstarfsfólk og fleiri pekki vel til Barnasáttmálans, einkum hinna fjögurra meginregla og að sáttmálinn sé hafður að leiðarljósi hverju sinni og ákvarðanir byggðar á meginreglunni um pað sem barninu er fyrir bestu.

prátt fyrir að staða barna á Norðurlöndunum hafi styrkst í lagalegum skilningi og að sáttmálinn segi til um að börn og heilsa barna skuli metin til jafns við aðra hópa fólks, er hætta á að tannvernd barna sitji eftir samanborið við tannvernd til dæmis fullorðinna. Ástæður geta verið margar. Skert afkastageta, p.e. skortur á starfsfólki eða öðrum nauðsynjum í tannlæknapjónustu getur pvingað starfsfólk til forgangsröðunar, sem getur leitt til pess að fullorðnir með undirliggjandi sjúkdóma og endurhæfingarpörf fái forgang umfram meðhöndlun barnatanna eða fyrirbyggjandi aðgerðir fyrir börn. Undanpáguáhrif hafa svipaðar afleiðingar og skert afkastageta og fela í sér að sjúklingar með lægri forgang fá pjónustu á undan sjúklingum með hærri forgang. pað sem ýtt getur undir slíkt er mishá greiðslupátttaka fyrir mismunandi heilbrigðispjónustu eftir aldri. Hætta er á að tilteknir sjúklingahópar eða tilteknar meðferðir séu arðbærari en aðrar og að endurgreiðslukerfið stýri forgangsröðun sjúklinga, umfram siðferðisleg sjónarmið. Aðrir pættir sem áhrif geta haft eru hvernig starfsstéttin forgangsmetur ólíka sjúklingahópa, hvaða hópar eru metnir í háum forgangi og hverjir í lágum, sem og aðgengi að starfsfólki með sérfræðimenntun á ólíkum sviðum. Meðhöndlun barna með umfangsmikla tannsjúkdóma eins og tannátu fylgir oft álag fyrir starfsfólk og pykir ekki borga sig. Í peim tilfellum pegar börn búa að auki við erfiðar félagslegar aðstæður og pegar tungumálahindranir eru til staðar flækjast verkefni tannlæknapjónustu enn frekar. Taka parf tillit til pessara pátta við skipulagningu umönnunar og eftirfylgni ef tannvernd skal veitt i samræmi við markmið Barnasáttmálans.

\section{Börn í félagslegu samhengi}

Börn njóta hvorki sterkrar stöðu sem einstaklingar né sjúklingar í heilbrigðispjónustu. Pess í stað eru pau nánast alfarið háð pví að forráðamenn peirra (foreldrar) 
eða hinar ýmsu stofnanir samfélagsins beri hag peirra og hagsmuni fyrir brjósti. Til að pað gangi upp parf t.d. tannlæknapjónusta að hafa góða pekkingu á aðstæðum barns í víðu samhengi, par með talið félagslegum páttum. Eins og hér verður lýst eru mjög sterk tengsl milli ýmissra félagslegra pátta og heilsu. Í einfölduðu máli er oft rætt um erfiðar félags- og fjárhagslegar aðstæður sem hafa áhrif á menntunarstig, tekjur, störf og umfang vinnu. Pegar börn eiga hlut að máli geta pessir pættir átt við barnið sjálft, en einnig forráđamann, sem flækir málið.

Erfiðar félagslegar aðstæður barna tengjast oft fátækt. Fátækt barna er hægt að skilgreina með mismunandi hætti og oft eru hugtökin háð aðstæðum og geta verið ónákvæm. Engu að sĩður er mikilvægt að vita hve stór hluti barna býr við bágar aðstæður, bæði svo unnt sé að skipuleggja heilsueflandi fræðslu og forvarnir sem beinast að ákveðnum samfélagshópum og til að mæta betur pörfum pessara barna og hafa betri skilning á t.d. pví hvað erfiðar fjárhagsaðstæður geta haft í för með sér fyrir barnið. pannig má vera að hlutir sem starfsfólk tannlæknapjónustunnar metur sem einfalda grunnpætti, svo sem tannbursti og tannkrem, séu í huga forráðamanna kostnaðarsamir og sömuleiðis ferðir til og frá tannlæknastofu. Raunverulegar aðstæður sem pessar hafa áhrif bæði á munnheilsu barna og aðgengi peirra að tannlæknapjónustu.

Í Evrópusambandinu er hlutfall barna undir 18 ára aldri sem tilheyra fjölskyldum með tekjur undir 60 eða 50 prósent af miðgildi tekna í landinu notað sem mælikvarði á fátækt barna (4). Árið 2013 var áætlað að 13\% allra barnafjölskyldna í Evrópusambandinu væru með tekjur undir 60\% af miðgildistekjum á tveimur af premur árum. Á Norðurlöndunum liggur samsvarandi tala á bilinu 3 til 5\%. Á Norðurlöndunum er hlutfall fátækra fjölskyldna hæst í Svípjóð, óháð pví hvaða skilgreining er notuð og hlutfall barna sem býr við fátækt hefur aukist í Svípjóð á ákveðnum tímabilum frá árinu 2010 til 2020.

Í Svípjóð styðst Barnaheill (Rädda barnen) við margvíslega útreikninga sem bæði taka mið af tekjustigi og framfærslustyrkjum pegar fátækt barna er skilgreind. Samkvæmt peim bjuggu 9,3\% allra barna í Svípjóð við fátækt árið 2016, p.e. næstum pví tíunda hvert barn (5). Fjárhagserfiðleikar, og par með barnafátækt, eru yfirleitt alvarlegri í fjölskyldum par sem foreldri er einstætt (10,9\% barnafátækt) eða pegar foreldrar eru af erlendum uppruna (19,6\% barnafátækt) og er áætlað að allt að 42\% barna, sem eiga einstæða foreldra af erlendum uppruna, búi við erfiðar fjárhagsaðstæður. Í pví samhengi er mikilvægt að benda á að áhrifamestu pættirnir pegar kemur að fátækt tengjast vinnu-og húsnæðismarkaði, svo sem atvinnuleysi og veikindum, en ekki pví að vera af erlendum uppruna. Áskoranir eru einnig stærri i stórborgum og pá sérstaklega á svæðum með mikinn félagslegan ójöfnuð. Séu áfram tekin dæmi um Svípjóð er barnafátækt 25\% í Malmö, en dreifingin er frá 8,7\% í Limhamn-Bunkeflo til 51,8\% í Rosengård. Pessi tvö svæði eru mjög ólík hvað varðar tekjur, búsetuform, menntunarstig og atvinnupátttöku (5). Tíðni tannátu er einnig mjög ólík milli svæðanna tveggja, meðal annars sýndi framkvæmdastjórnin í Malmö fram á að prátt fyrir markvissar fyrirbyggjandi aðgerðir voru sex sinnum fleiri 6 ára börn með tannátu í Rosengård en í Bunkeflo.

Ýmsir aðrir pættir geta haft áhrif á getu fjölskyldu eða forráðamanns til að styðja, ala upp og standa vörð um hagsmuni barns. Markmið er að uppeldisskilyrði séu góð, bæði hvað snertir líkamlega og andlega heilsu. Slíkir pættir geta verið andleg veikindi eða vímuefnanotkun forráðamanna en einnig aðrir streituvaldar í daglegu lífi. Sem dæmi er algengara að foreldrar barna með fötlun pjáist af langvinnum sjúkdómum en aðrir. pað hefur í för með sér að barn getur af og til búið við tvöfalda áskorun. Auk félagslegra áskorana í formi fjárhagslegra erfiðleika getur vanheilsa forráðamanna aukið flækjustigið, eða fötlun eða langvinn veikindi barns gert fjárhag enn meira ípyngjandi. Í pví ljósi er nauðsynlegt að tannlæknapjónusta taki mið af bæði kerfisbundnum páttum sem valda erfiðum félagslegum aðstæðum, svo sem með pekkingu á lífskjörum og barnafátækt á tilteknu landfræðilegu svæði, ásamt einstaklingsbundnum páttum hvers barns fyrir sig, svo sem ef umönnun barns er ábótavant eða ef barnið er með krefjandi sjúkdóm eða fötlun. pað krefst góðrar pekkingar á Barnasáttmálanum og að tannlæknapjónusta sé skipulögð pannig að fræðslu-og forvarnarstarf sé unnið í samstarfi við aðrar stofnanir samfélagsins, t.d. heilsugæslu, skóla, heilsu-og sjúkrahúspjónustu og félagspjónustu og sé i stakk búin til að bregðast við pörfum einstakra barna ef talið er að velferð barns sé í hættu.

\section{Félags-og fjárhagslegir pættir og tannheilsa}

Ýmsar rannsóknir á Norðurlöndunum sýna tengsl milli félags-og fjárhagspátta og tannátu hjá börnum og ungmennum. Í Svípjóð var nýlega sýnt fram á sterk tengsl milli fyrrnefndra pátta og tannátu hjá börnum og ungmennum á aldrinum 3-19 ára. Munurinn var meiri eftir pví sem börnin voru yngri. Landfræðileg staðsetning hafði meira að segja en mismunandi tannlæknastofur (6). Svipaðar niðurstöður hafa fengist í öðrum rannsóknum á Norðurlöndunum (7-10). pættir á borð við pjóðerni, 
menntunarstig foreldra, tekjur og atvinnu/atvinnuleysi, geðsjúkdóma i fjölskyldunni og skort á foreldrahæfni virðast hafa áhrif á tannátuáhættu barna og unglinga.

Árið 2013 gerði heilsu- og velferðarráðuneyti Svípjóðar rannsókn á tengslum tannheilsu barna og foreldra og notkun tannlæknapjónustu. Pví verri sem tannheilsa foreldra var, pví meiri hætta var á að barn hefði tannátu. Félagslegar aðstæður foreldra, ungir eða einstæðir foreldrar, lágt menntunarstig, fjárhagslegar aðstæður, foreldrar frá löndum utan Norðurlanda og Vestur-Evrópu og vilji peirra til að piggja tannlæknapjónustu hefur bæði áhrif á tannátuáhættu barna og hversu oft börnin sækja tannlæknapjónustu. Börn sem búa á efnalitlum svæðum par sem hlutfall innflytjendahópa er hátt eru í aukinni áhættu á tannátu og líklegri til að nýta ekki tannlæknapjónustu, en börn á efnameiri svæðum (11). Ítarleg viðtöl við foreldra barna sem ekki hafa nýtt tannlæknapjónustu sýna að pessar fjölskyldur eru oft undir miklu álagi í daglegu lífi og að pær eru ekki færar um að setja tannlæknapjónustu barna sinna í forgang (12).

\section{Börn í umönnun og tannheilsa}

Börnum sem ekki búa hjá báðum foreldrum og börnum sem eru í umsjá fósturfjölskyldna, er hlutfallslega oftar vísað til sérhæfðra tannlækna vegna umfangsmikillar meðferðarparfar og vandamála við meðferð (13). Í Svípjóð eru um $4 \%$ barna á einhverjum tímapunkti frá fæðingu til 18 ára aldurs í umönnun af yfirvöldum, til dæmis fósturfjölskyldu, ungmennaheimilis eða stofnunar (svonefnd SiS-heimili fyrir ungmenni sem glíma við alvarleg andleg og félagsleg vandamál og vímuefnanotkun). Rannsóknir frá ýmsum löndum hafa sýnt að pessi börn búi við verri líkamlega- og andlega heilsu og tannheilsu, en önnur börn og að pau séu líklegri til að verða af tannlæknapjónustu (11, 14-17). Nýleg yfirlitsgreining sýnir skort á skipulögðum ferlum sem tryggja að börn í fóstri njóti heilbrigðis-, sjúkrahús- og tannlæknapjónustu. Tannlæknapjónustan nær ekki til peirra, pau fara hvorki í reglulegar skoðanir né fá sömu meðferð og önnur börn, hvorki áður en pau eru sett í fóstur né á fóstrunartímabili og engin breyting verður á eftir að dvöl lýkur (18).

\section{Heimilislaus börn og tannheilsa}

Heimilisleysi hefur mikil áhrif á líkamlega og andlega heilsu barna. Rannsóknir sýna tengsl milli ótryggs húsnæðis, pröngrar búsetu og slæmrar heilsu, minni líkamspyngdar og hættu á proskavandamálum ungra barna (19). Heimilislaus börn búa einnig við aðra áhættupætti á borð við fátækt, fólksflutninga, vímuefnamisnotkun og ofbeldi. Samkvæmt umboðsmanni barna (20) fer heimilislausum börnum í Svípjóð fjölgandi en skortur er á tölfræðilegum gögnum.

Að eiga ekki heimili og neyðast til að flytja oft veldur óöryggi. Tíð skólaskipti eða löng leið til skóla og vina veldur streitu og einangrun. Fjölskyldur hafa einnig lýst erfiðleikum við að komast i samband við tannlæknapjónustu og pekkingarleysi innan pjónustunnar um pær reglur sem gilda (21). Börn sem búa við heimilisleysi eru líklegri til að hafa slæma tannheilsu. Háar tannátutölur hafa verið birtar meðal heimilislausra barna m.a. í Bandaríkjunum, en upplýsingar um Norðurlöndin skortir (22).

\section{Fólk á flótta og tannheilsa}

Börn á flótta eru i sérstaklega viðkvæmri stöđu. Aðgangur barna að tannlæknapjónustu er mismunandi eftir pví hvar í hælisleitarferlinu pau eru. Aðeins pegar pau hafa fengið dvalarleyfi eru pau kölluð inn í reglulegar skoðanir og aðeins pá er tannheilsa peirra talin með í tölfræði. Hinsvegar er klínísk reynsla á pessu sviði pó nokkur, ekki síst frá flóttamannabylgjunni árið 2015, sem sýnir að munn-og tanntengd vandamál eru veruleg hjá umtalsverðum hluta barna á flótta. Samkvæmt Barnasáttmálanum er ekki heimilt að mæta tannverndarpörf pessara barna með öðrum hætti en annarra barna. Árið 2017 gerði umboðsmaður barna i Svípjóð könnun á meðal skólahjúkrunarfræðinga. Skýrslan (23) sýnir að andleg vandamál eru algeng á meðal skólabarna sem nýflutt eru til landsins, einnig að börn sem búið hafa lengi í landinu fari á mis við reglulegar læknaskoðanir.

\section{Aðgerðir}

Vísindamenn hafa í áratugi reynt að vinna bug á ójöfnuði í munnheilsu vegna félagslegra pátta, en prátt fyrir pað sýna rannsóknir á börnum í Skandinavíu og víðar að félagslegir pættir hafa enn mikil áhrif. Verkefnið er vandasamt af ýmsum ástæðum. Óöfnuður í munnheilsu verður ekki purrkaður út með pví að beina munnheilsuaðgerðum eingöngu að peim verst settu (6). Á pann hátt verða aðeins til nýir hópar sem alast upp við sömu aðstæður og sömu undirliggjandi pætti sem skapa ójöfnuð, einstaklings-og fjölskyldukjör, lífsstíl, nærumhverfi, siði og gildi o.s.frv. Tannlæknastofur geta aðeins að litlu leyti haft áhrif á pessa pætti, jafnvel pótt sjúklingur fái bestu mögulegu meðferð. Engu að síður er mikilvægt að starfsemi tannlæknastofa sé sampætt við pau úrræði sem ákveðið er að beita til pess að minnka félagslegan ójöfnuð. 


\section{Heilsueflandi aðgerðir}

Almennar heilsueflandi aðgerðir sem beinast að almenningi í heild, einnig nefndar "upstream public health approach" (24), eru pað eina sem auðveldað geta börnum/foreldrum að bæta munnheilsu. Sem dæmi getur tannlæknapjónustan tryggt kerfisbundið og bindandi samstarf við aðra aðila sem vinna með börnum, svo sem heilsugæslustöðvar og leikskóla, og komið á bindandi samningum um tannburstun og fræðslu um mataræði. Heilsueflandi úrræði fela einnig i sér miðlun nútímapekkingar á meðferð tannátu, byggða á vísindalegum grunni, m.a. að tannáta sé meðhöndluð sem sjúkdómur, helst á glerungsstigi (án viðgerðar) til að draga úr pörf tannfyllinga (25). Lögbundinn réttur foreldra á upplýsingum um heilsufar barns og vali á aðgengilegri og rættmætri pjónustu (26) felur í sér að foreldrar skulu einnig fá nauðsynlegar upplýsingar um hvenær barnið greinist með tannátu í glerungi, hvort meinið sé staðbundið og hvenær pörf er á meðferð án viðgerðar. Án slíkra upplýsinga geta foreldrar ekki lagt sitt að mörkum við að halda glerungsúrkölkunum hreinum. Að auki ber að upplýsa foreldra um að góð munnheilsa frá unga aldri hafi jákvæð áhrif á almenna heilsu og munnheilsu i framtíðinni. Best væri ef "nútímalegur fræðslupakki”, próaður í samvinnu við sérfræðinga í almannatengslum, yrði birtur á samfélagsmiðlum með reglulegu millibili til að foreldrar séu undirbúnir fyrir fyrstu heimsókn barns til tannlæknis.

\section{Almennar forvarnaraðgerðir}

Eitt dæmi um forvarnaraðgerð, sem beinist að öllum íbúum landsins („,population approach“), og sýnt hefur góð forvarnaráhrif, er tannburstun með flúortannkremi tvisvar á dag frá uppkomu fyrstu tannar (27). Dæmi um aðra víðtæka aðferð af sama tagi i Skotlandi, sem sýnt hefur tannátuhemjandi áhrif i öllum pjóđfélagshópum, er "Childsmile intervention programme" (28).

\section{Sértækar forvarnaraðgerðir}

Fyrir áhættuhópa er yfirleitt pörf á samhliða, sértækum forvarnaraðgerðum („High-risk approach“) (29), sem ekki eru eingöngu í höndum tannlæknapjónustunnar. Forvarnaraðgerðir par sem unnið er eftir "The common risk factor approach" (30) í pverfaglegri samvinnu við aðra heilbrigðispjónustu, hefur meiri áhrif á sameiginlega heilsutengda áhættupætti, en án slíkrar samvinnu (29). Par sem tannátutíðni af völdum félagslegra pátta er mest í barnæsku (Early Childhood Caries, ECC) (31) mælast vísindalegar ráðleggingar til pess að sértækar aðgerðir hefjist eins fljótt og hægt er og gjarnan fyrir fæðingu með fræðslu barnshafandi kvenna (32). Eins og áður er getið ýtir tannheilbrigði á unga aldri undir betri tannheilsu á fullorðinsárum (33). Box 1 og 2 ásamt Mynd 1 sýna mismunandi staðreyndir og aðgerðir.

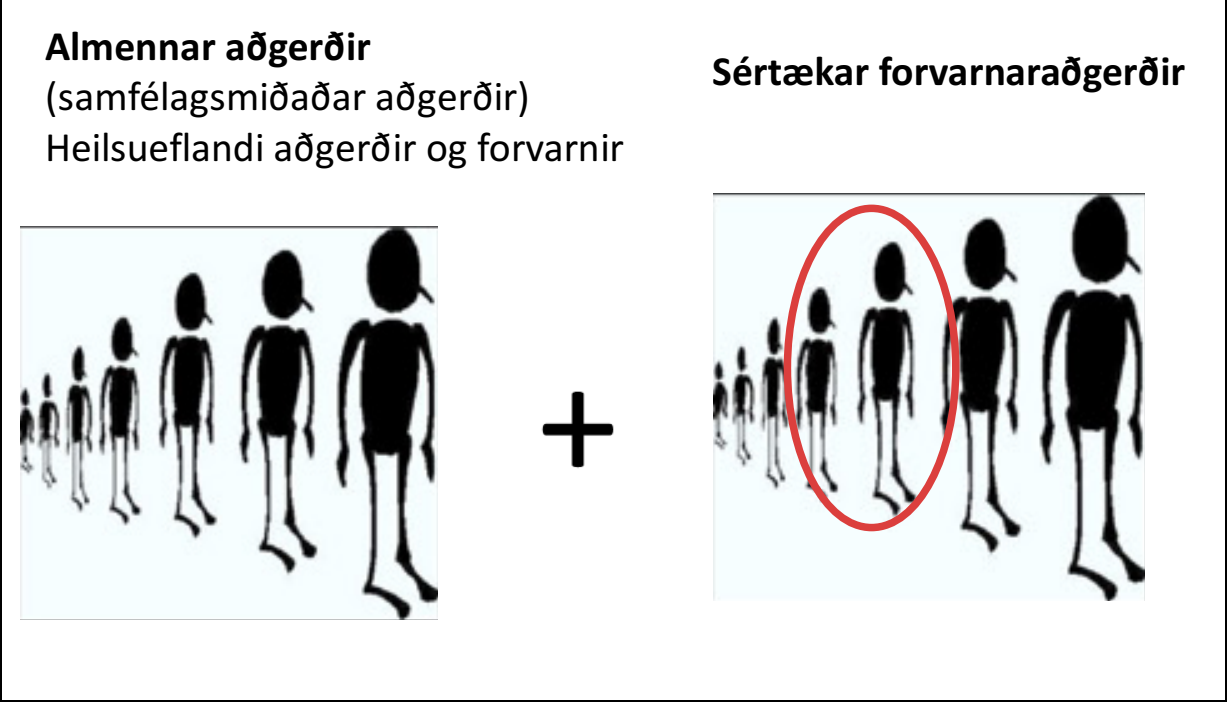

Mynd 1. Áhættuhópur barna sem býr við erfiðar félagslegar aðstæður parfnast bæði almennra- og sértækra forvarnaraðgerða (bakgrunnsmynd sótt á Google).

Fig. 1. The risk group of socially vulnerable children needs at the same time population-based and selective preventive measures (wallpapers taken from Google). 


\section{Staðreyndabox 1}

Aðgerðir fyrir samfélagið í heild

Heilsueflandi aðgerðir

Tekist á við mismunandi undirliggjandi orsakir lakrar munnheilsu til að auðvelda fólki að bæta munnheilsu Forvarnaraðgerðir

Aðgerðir sem hafa pað markmið að draga úr áhættu

\section{Aðgerðir sem eingöngu beinast að áhættuhópum \\ Sértækar forvarnaraðgerðir}

Áhersla beinist að áhættuhópum. Faraldsfræðileg og/eða félagsfræðileg gögn notuð til að bera kennsl á hópana.

\section{BÖRN SEM BÚA VIĐ ERFIĐAR FÉLAGSLEGAR} AĐST/EOUR PARFNAST ALLRA PESSARA AĐGERĐA SVO VON SÉ TIL PESS AĐ DRAGA MEGI ÚR ÓJÖFNUĐI

\section{Staðreyndabox 2}

Börn sem búa við erfiðar félagslegar aðstæður mynda stóran barnahóp sem býr við aukna áhættu á slæmri tannheilsu snemma á ævinni. Tannlæknapjónustan nær ekki til pessara barna í sama mæli og annarra barna, sem leiðir til skertrar tannverndar og hættu á verri munnheilsu ævilangt. Einstaklingsmiðaðar aðgerðir nægja ekki til að draga úr heilsutengdum ójöfnuði pessara barna. Ójöfnuður í munnheilsu ólíkra hópa kallar að auki á heilsueflandi fræðslu og forvarnir sem beinast að ákveðnum hópum. Til að pað gangi upp parf tannlæknapjónustan að vinna með öðrum stofnunum samfélagsins að pví að bera kennsl á hópana og beita heilsueflandi aðgerðum.

Viðeigandi bakgrunnsupplýsingar eru nauðsynlegar til að unnt sé að sérsníða sértækar forvarnaraðgerðir. Rannsóknir eru pverfaglegar og samvinna mismunandi fagaðila við meðhöndlun og túlkun gagna eykur gæði rannsókna og vonandi einnig tannlæknapjónustunnar í kjölfarið. Samkeyrsla við aðra opinbera gagnagrunna, af félags-, fjárhags, og menningarlegum toga, gæti einnig komið að gagni.

\section{Áskoranir}

Norðurlönd hafa sérstöðu pegar kemur að skipulagi tannlæknapjónustu og aðgengi að faraldsfræðilegum gögnum um tannátu barna og unglinga, pótt misræmis gæti í gagnaöflun, um hvaða aldurshópa gögnum er safnað og hvaða munnheilsupættir verða fyrir valinu (1). Markmið er að heilbrigðar nýuppkomnar tennur haldist heilar og ef tannáta myndast, að komið sé í veg fyrir að hún nái til tannbeins. Hefðbundin gagnasöfnun um tíðni tannátu sem nær inn í tannbein, p.e. pegar nútímameðferðir við tannátu hafa mistekist (1), samræmist pví ekki forvarnaraðgerðum nútímans gegn tannátu (32). Gögn frá svokölluðum lykilaldurshópum í Noregi (5-, 12- og 18 ára) gagnast pví ekki í skipulagningu sértækra aðgerða gegn ECC (tannátu í barnæsku).

Eigi sértækar forvarnaraðgerðir gegn tannátu að skila árangri parf val áhættuhópa að vera úthugsað. pegar ná á til einstaklinga sem búa við erfiðar félagslegar aðstæður eða tilheyra minnihlutahópum, hafa upplýsingar úr munnheilsuskrám verið samkeyrðar með félags-, menningar- og fjárhagslegum gögnum frá hinu opinbera $(7,28)$. Einnig hefur landfræðileg áhættugreining verið gerð út frá hlutfallslegri tannátuáhættu í suðvesturhluta Svípjóðar (34), með notkun landakorta, „Geo-map” (35). Aukið umfang faraldsfræðilegra gagna hefur í för mér sér aukna pörf fyrir gagna-og tölfræðiaðstoð, bæði við vinnslu og túlkun upplýsinga.

\section{Dæmi um sértækar aðgerðir gegn ecc}

Orsakapættir ECC eru margpættir (36), en meginpættir eru félags-, fjárhags- og menningarlegs eðlis. ECC er flókið vandamál sem kallar á margpætt inngrip par sem vægar upphafsaðgerðir duga yfirleitt ekki (37). Rafrænir spurningalistar fyrir foreldra sem yfirfæra svör yfir í gagnagrunna kosta lítið og eru ætlaðir til að afla bakgrunnsupplýsinga tímanlega. Best væri að spurningar um munnheilsu væru hluti upplýsinga sem aflað er á heilsugæslustöðvum, hvort sem um er að ræða pekkingu og viðhorf til munnheilsu eða áherslu foreldra á munnheilsu, fæðuvenjur eða tannburstun foreldra og barns með flúortannkremi og brjóstagjöf móður. Munnheilsuráð ættu að vera hluti almennrar heilsuráđgjafar fyrir barnshafandi konur sem eru móttækilegar fyrir slíkum upplýsingum við að halda glerungsúrkölkunum hreinum [38]. Einnig skiptir upprunaland foreldra innflytjenda máli (7) pví ákveðnir menningarheimar eru útsettari fyrir vandkvæðum tengdum munnheilsu. Fjölskyldur með slíkan bakgrunn hafa pörf 
fyrir sértækar og sérsniðnar forvarnaraðgerðir, sem taka tillit til menningarpátta, oft í samstarfi við forsprakka minnihlutahópa eða starfsfólk tannlæknapjónustu með innflytjendabakgrunn. Börn í aukinni tannátuáhættu ætti almennt að boða í skoðun strax við eins árs aldur, par sem starfsfólk skráir tannátu í glerungi og umfang tannsýklu. pegar barnið er orðið eldra og fleiri tennur komnar má með tölfræðilegum útreikningum afla upplýsinga um hvaða aðgerðir á tönnum/tannflötum gagnist best, s.s. flúorlökkun, til að tannátan nái ekki inn í tannbein.

Sértækar aðgerðir fyrir eldri áhættuhópa virðast einnig skila árangri, en enn skortir upplýsingar um alla aldurshópa (39). Sama hvaða aldurshópur barna, sem býr við erfiðar félagslegar aðstæður, er valinn sem markhópur, er mikilvægt að peir áhættupættir sem eru ríkjandi i einum áhættuhópi, eru ekki endilega peir sömu og í öđrum hópi, jafnvel pótt aldur sé sá sami. Pví ber að greina áhættumynstur markhópsins sem aðgerðir beinast að áður en aðgerðum er hrint í framkvæmd. Mikilvægt er að sannfæra pá sem taka ákvarðanir um að pær byggi á vísindalegri pekkingu (32).

\section{Niðurstöður}

prátt fyrir Barnasáttmálann búa mörg börn á Norðurlöndum við erfiðar félagslegar aðstæður, sem hafa í för með sér slæma munnheilsu. pau purfa bæði fræðslu og forvarnaraðgerðir sem beinist að samfélaginu í heild, en að auki sértækar forvarnaraðgerðir fyrir pann markhóp. Munnheilsa nær til margra ólíkra sviða en rannsóknir beinast aðallega að tannátu pví hún veldur mestum usla hjá börnum. prátt fyrir pað er mikill félagslegur ójöfnuður hvað aðra tanntengda sjúkdóma varðar og pekkingu skortir um æskilegustu meðferðarúrræði peirra svo draga megi úr ójöfnuði. Vitað er að umbætur á munnheilsu barna í erfiðum félagslegum aðstæðum purfa að byggja á samvinnu við aðra samfélagspjónustu, svo sem heilsugæslu, skóla og félagspjónustu.

\section{Yfirlýsing vegna mögulegra hagsmunaárekstra}

Höfundar staðfesta að engir hagsmunaárekstrar voru við gerð greinarinnar.

Höfundar hafa ekki pegið fjárframlag vegna hennar.

\section{Heimildir}

1. Skeie MS, Klock KS. Scandinavian systems monitoring the oral health in children and adolescents; an evaluation of their quality and utility in the light of modern perspectives of caries management. BMC Oral Health 2014;14:43.

2. SVERIGES REGERING. Barnkonventionen. 2020. [sótt 1. mars 2020] Sótt af: https:// www.regeringen.se/49b764/contentassets/8caaeabf49834f16aa52df2108837b2d/ fns-konvention-om-barnets-rattigheter-so-199020

3. NORDIC COUNCILS OF MINISTERS. Do rights!: Nordic perspectives on child and youth participation. [vefsvæði] Copenhagen DK : Nordic Council of Ministers, 2016 [sótt 1. mars 2020] Sótt af: https://norden.diva-portal.org/smash/get/diva2:930511/ FULLTEXT01.pdf

4. NORDENS VÄLFÄRDSCENTER. Fokus på barnfattigdom. 2013. ISBN: 978-877919-093-1 [vefsvæði] [sótt 1. mars 2020] Sótt af: https://nordicwelfare.org/ wp-content/uploads/2017/10/BarnfattigdomSLUT.pdf

5. RÄDDA BARNEN. Barnfattigdom i Sverige. Rapport 2018. ISBN: 978-91-7321-3769 [vefsvæði] [sótt 1. mars 2020] Sótt af: https://resourcecentre.savethechildren.net/ node/14233/pdf/rb_rapport_2018_final.pdf

6. Kramer ACA, Pivodic A, Hakeberg M et al. Multilevel analysis of dental caries in Swedish children and adolescents in relation to socioeconomic status. Caries Res 2019;53:96-106.

7. Christensen LB, Twetman S, Sundby A. Oral health in children and adolescents with different socio-cultural and socio-economic backgrounds. Acta Odontol Scand 2010;68:34-42.

8. Julihn A, Ekbom A, Modéer T. Migration background: a risk factor for caries development during adolescence. Eur J Oral Sci 2010;118:618-25.

9. Wigen TI, Espelid I, Skaare AB et al. Family characteristics and caries experience in preschool children. A longitudinal study from pregnancy to 5 years of age. Community Dent Oral Epidemiol 2011;39:311-7.

10. Östberg AL, Kjellström AN, Petzold M. The influence of social deprivation on dental caries in Swedish children and adolescents, as measured by an index for primary health care: The Care Need Index. Community Dent Oral Epidemiol 2017;45:233-41.

11. SOCIALSTYRELSEN. Sociala skillnader i tandhälsa bland barn och unga. Underlagsrapport till barns och ungas hälsa, vård och omsorg 2013. [vefsvæði] [sótt 1. mars 2020] Sótt af: https://www.socialstyrelsen.se/Lists/Artikelkatalog/ Attachments/19101/2013-5-34.pdf

12. Hallberg U, Camling E, Zickert I et al. Dental appointment no-shows: why do some parents fail to take their children to the dentist? Int J Paediatr Dent 2008;18:27-34.

13. Gustafsson A, Arnrup K, Broberg AG et al. Psychosocial concomitants to dental fear and behaviour management problems. Int J Paediatr Dent 2007;17:449-59.

14. Köhler M, Emmelin M, Hjern A et al. Children in family foster care have greater health risks and less involvement in Child Health Services. Acta Paediatr 2015;104:508-13.

15. Kling S, Vinnerljung B, Hjern A. Somatic assessments of 120 Swedish children taken into care reveal large unmet health and dental care needs. Acta Paediatr 2016;105:416-20.

16. Randsalu LS, Laurell L. Children in out-of-home care are at high risk of somatic, dental and mental ill health. Acta Paediatr 2018;107:301-6.

17. Vinnerljung B, Hjern A. Health care in Europe for children in societal out-of-home care. Rapport till EU-kommissionen från MOCHA - Models of child health appraised. London: MOCHA/Imperial College, 2018. [vefsvæði] [sótt 1. mars 2020] Sótt af: https://www.childhealthservicemodels.eu/wp-content/uploads/Mocha-report-Childrenin-OHC-May-2018.pdf

18. Mensah $\mathrm{T}$, Hjern $\mathrm{A}$, Håkanson $\mathrm{K}$ et al. Organisational models of health services for children and adolescents in out-of-home care: health technology assessment. Acta Paediatr 2020;109:250-7.

19. Cutts DB, Meyers AF, Black MM et al. US Housing insecurity and the health of very young children. Am J Public Health 2011;101:1508-14.

20. BARNOMBUDSMANNEN. Inget rum för trygghet - barn och unga om vräkning och hemlöshet Temarapport Max18 - 2016. [vefsvæði] [sótt 1. mars 2020] Sótt af: https:// www.barnombudsmannen.se/globalassets/dokument-for-nedladdning/publikationer/ inget_rum_for_trygghet_2016_final.pdf

21. Björkhagen Turesson $A$, ed. Hemlösa barns vardagsliv i Malmö. Utifrån ett barnrättsperspektiv. FoU rapport 2019:4. Malmö: Malmö universitet. 2019. ISBN 978-91-7877-047-2, 978-91-7877-046-5, ISSN 1650-2337, [sótt 1. mars 2020] Sótt af: http://muep.mau.se/bitstream/handle/2043/30701/978-91-7877-047-2_Turesson_ epub\%20(1).pdf?sequence=2

22. Chiu SH, Dimarco MA, Prokop JL. Childhood obesity and dental caries in homeless children. J Pediatr Health Care 2013;27:278-83.

23. BARNOMBUDSMANNEN. Nyanlända barns hälsa. Delrapport I Barnombudsmannens årstema 2017 - Barn på flykt. Stockholm 2017 [sótt 1. mars 2020] Sótt af: https:// www.barnombudsmannen.se/globalassets/dokument-for-nedladdning/publikationer/ rapport-nyanlanda-barns-halsa.pdf

24. Watt RG. Introduction. Í: Sheiham A, Bönecker M, ritstj. Promoting Children 's Oral Health: Theory \& Practice. 1. útg. Sao Paulo: Quintessence Editora Ltd, 2006;1-12.

25. Raadal M, Espelid I, Crossner C. Non-operativ vs operativ behandling av karies blant barn og unge. Er det tid for å endre strategi? Nor Tannlegefor Tid 2011;121:10-7. 
26. STORTINGET. Lovvedtak 109 (2016-2017). Vedtak til lov om endringar i pasient- og brukarrettslova, helsepersonellova m.m. (styrking av rettsstillinga til barn ved yting av helse- og omsorgstenester m.m.). §3-1 og §3-3: Rett til medvirkning. Informasjon til pasientens eller brukerens nærmeste pårørende 2017.

27. STATENS BEREDNING FÖR MEDICINSK UTVÄRDERING. Att förebygga karies. En systematisk litteraturöversikt. Stockholm: Statens beredning för medicinsk utvärdering (SBU), 2002. SBU-rapport 161;45-57. [sótt 1. mars 2020] Sótt af: https:// www.sbu.se/contentassets/84b23d321fd3462c93d996088c925344/kapitel_3_fluor. pdf

28. McMahon AD, Blair Y, McCall DR et al. Reductions in dental decay in 3-year old children in Greater Glasgow and Clyde: repeated population inspection studies over four years. BMC Oral Health 2011;11:29.

29. Watt RG. Strategies and approaches in oral disease prevention and health promotion. Bull World Health Organ 2005;83:711-8.

30. Sheiham A, Watt RG. The common risk factor approach: a rational basis for promoting oral health. Community Dent Oral Epidemiol 2000;28:399-406.

31. Wennhall I, Matsson L, Schröder U et al. Caries prevalence in 3-year-old children living in a low socio-economic multicultural urban area in southern Sweden. Swed Dent J 2002;26:167-72.
32. Pitts $\mathrm{N}$, Amaechi $\mathrm{B}$, Niederman $\mathrm{R}$ et al. Global oral health inequalities: dental caries task group--research agenda. Adv Dent Res 2011;23:211-20.

33. Isaksson H, Alm A, Koch G et al. Caries prevalence in Swedish 20-year-olds in relation to their previous caries experience. Caries Res 2013;47:234-42.

34. Strömberg U, Magnusson K, Holmén A et al. Geo-mapping of caries risk in children and adolescents - a novel approach for allocation of preventive care. BMC Oral Health 2011;11:26.

35. Elliot PWJ, Best NG, Briggs DJ. Spatial epidemiology: Methods and applications. Oxford: Oxford University Press, 2000.

36. Harris R, Nicoll AD, Adair PM et al. Risk factors for dental caries in young children: a systematic review of the literature. Community Dent Health 2004;21 (Supp 1):71-85.

37. O'Mullane D, Parnell C. Early childhood caries: a complex problem requiring a complex intervention. Community Dent Health 2011;28:254.

38. Feldens CA, Vitolo MR, Drachler MDL. A randomized trial of the effectiveness of home visits in preventing early childhood caries. Community Dent Oral Epidemiol 2007:35:215-23.

39. Skeie MS, Klock KS. Dental caries prevention strategies among children and adolescents with immigrant - or low socioeconomic backgrounds- do they work? A systematic review. BMC Oral Health 2018;18:20.

English Summary

\title{
Oral Health challenges in children from socially deprived areas
}

\author{
GUNILLA KLINGBERG, DDS, DR.ODONT, DEAN, PROFESSOR PEDIATRIC DENTISTRY, FACULTY OF ODONTOLOGY, \\ MALMÖ UNIVERSITY, SWEDEN \\ KARIN RIDELL, DDS, DR.ODONT, ASSISTANT PROFESSOR PEDIATRIC DENTISTRY, FACULTY OF ODONTOLOGY, \\ MALMÖ UNIVERSITY, SWEDEN \\ MARIT SLÅTTELID SKEIE, DDS, DR.ODONT, PROFESSOR EMERITA, DEPARTMENT OF CLINICAL DENTISTRY, \\ UNIVERSITY OF BERGEN, NORWAY AND THE DENTAL HEALTH SERVICE'S CENTER, CENTRAL NORWAY (TKMIDT), \\ TRONDHEIM, NORWAY
}

\section{ICELANDIC DENTAL JOURNAL 2020; 38: 88-95} doi: 10.33112/tann.38.1.10

Everyone who works with children should know about the UN Convention on the Rights of the Child, which states that all children should have the same right to highest attainable standard of health. Despite good oral health in the Nordic countries, studies show that children living in socially deprived environments have a greatly increased risk of poor oral health. These children are not reached by preventive measures, they more frequently do not show up for dental appointments and they receive less dental care than others. Therefore, in addition to a more general population based prevention approach, a special high-risk approach is needed to reach children in socially deprived areas. It is also important that the promotion and prevention efforts start from an early age. There are large knowledge gaps regarding the effects of different prevention and treatment strategies, and health economic analyzes are rare. It is a particular challenge to systematically document and evaluate oral health promotion and prevention directed at children in socially vulnerable environments to enable research. There is a need for interdisciplinary research also including clinicians. The vision must be health equity and that both health promotion and preventive measures contribute to closing the oral health gap between different social groups.

Keywords: Dental services, children, social and financial aspects, oral health, prevention. Correspondence: Gunilla Klingberg, Malmö universitet, Odontologiska fakulteten, SE 20506 Malmö, Sverige gunilla.klingberg@mau.se

Accepted for publication May 18, 2020 